\title{
ARTICLE
}

\section{Group Transactions, Transfer Pricing and Litigation: Evidence from Portugal}

\author{
António Martins ${ }^{* *}$, Sandrina Correia ${ }^{* * *}$ \& Daniel Taborda*****
}

\begin{abstract}
In Portugal, in the wake of the introduction of tax arbitration in 2011, courts have ruled in several cases involving transfer pricing (TP) judicial conflicts. The research questions that this article addresses are: What are the core issues in TP litigation in Portugal? Do they follow international trends? What is the predominant outcome of arbitration rulings, and why do tax authorities experience defeat so many TP cases?

Based on the total (thirty-two) TP arbitration cases decided in Portugal from 2012 to 2017, the authors find that tax administrations (TA) were successful in only three cases. Courts also found that tax audit reports often misused the comparability concept, and the methods that were used were also often disallowed by arbitrators. Therefore, TAs should proceed with caution in audits and seek robust foundations to TP adjustments. Multinational groups must also carefully substantiate their related party transactions in order to minimize audit risk and compliance costs of taxation.
\end{abstract}

Keywords: Group transactions, transfer pricing, tax arbitration, Portugal

\section{INTRODUCTION}

Multinational businesses are increasingly being audited by tax authorities (TA) regarding transfer prices (TP) that are used in related party transactions. ${ }^{1}$ The arm's length principle is the cornerstone of tax legislation, and comparable transactions between independent parties are usual benchmarks used by taxpayers, TAs, and courts when litigation occurs in a TP context. ${ }^{2}$

The Portuguese TA has been increasingly auditing multinational firms, and tax adjustments based on TP are becoming frequent. ${ }^{3}$ Considering that TP audits are primarily directed at multinational groups ${ }^{4}$ that have resources to litigate, courts have often ruled in such disputes. ${ }^{5}$ In Portugal, in the wake of the introduction of tax arbitration in 2011, courts had to adjudicate many TP cases. ${ }^{6}$

TP is a complex issue. Companies, tax auditors, and courts must address intra group specific transactions, unique assets, or financial arrangements that are not usually observable between independent parties. $^{7}$ Additionally, the comparability principle involves the analysis of economic conditions, risks, functions performed, contractual terms and market strategies that may be hard to apprehend. ${ }^{8}$

In this context, the research questions addressed in this article are: What are the core issues in TP litigation in Portugal? Do they follow international trends? What is the predominant outcome of arbitration court rulings, and why do TAs experience defeat in so many cases?

\section{Notes}

* The authors are grateful for helpful comments from two anonymous reviewers. The usual disclaimer applies.

** University of Coimbra and CeBER Research Centre, School of Economics, Av Dias da Silva 165; 3004-512 Coimbra. Email: amartins@fe.uc.pt.

*** University of Coimbra, School of Economics, Av Dias da Silva 165; 3004-512 Coimbra. Email: sandrilipa@hotmail.com.

***** University of Coimbra and CeBER Research Centre, School of Economics, Av Dias da Silva 165; 3004-512 Coimbra. Email: danieltaborda@fe.uc.pt. See OECD, Transfer Pricing Guidelines for Multinational Enterprises (OECD Publishing 2017).

See A. Haris Muhammadi, Z. Ahmed \& A. Habib, Multinational Transfer Pricing of Intangible Assets: Indonesian Tax Auditors' Perspectives, 24(3) Asian Rev. Accounting 313 (2016); W.E. Bradley, Transfer Pricing: Increasing Tension between Multinational Firms and Tax Autborities, 7(2) Accounting \& Tax'n 65 (2015).

See D. Barros \& G. Teixeira, Prẹcos de Transferência e o Caso Português (Vida Económica 2004).

See J. T. Gama coord., Cadernos Preços de Transferência (Almedina 2013).

See J. Loeprick, J. Cooper, R. Fox \& K. Mohindra, Transfer Pricing and Developing Economies: A Handbook for Policy Makers and Practitioners, World Bank (16 Nov. 2017), http:// dx.doi.org/10.1596/978-1-4648-0969-9 (accessed 16 Apr. 2020).

6 See F. S. Câmara, Making a Choice in Portugal: Taking Your Case to the Tax Arbitration Tribunals or Tax Judicial Courts?, 78(2) Tax Notes Int'l 173 (2015).

See V. Chand, Transfer Pricing Aspects of Intra - Group Loans in Light of the Base Erosion and Profit Shifting Action Plan, 44(12) Intertax 885 (2016).

See OECD, supra n. 1 . 
Based on thirty-two TP cases, including all of the arbitrated cases in Portugal from 2012 to 2017, the authors ascertain that TAs were successful in only three cases. Courts found that tax audit reports often misused the comparability concept by using operations and prices as comparables that did not fulfil the requirements established in TP regulations. Therefore, TAs should be more diligent in audits and seek robust foundations to TP adjustments. Multinational groups must also carefully substantiate their related party transactions in order to minimize audit risks and compliance costs of taxation.

The article contributes to the literature by presenting empirical evidence of TP litigation outcomes. To the best of the authors' knowledge, there are no studies about TP jurisprudential trends based on arbitration cases. The findings afford TAs the opportunity to draw upon the Portuguese experience regarding audit procedures and their validity in court rulings.

Tax arbitration is not common in many countries. Thus, the Portuguese experience can be beneficial to foreign jurisdictions that are possibly considering the introduction of alternative resolution mechanisms, such as arbitration, in a sensitive area such as taxation. Even if arbitration is sometimes used in disputes related to international tax treaties, the arbitration of domestic disputes is not common. ${ }^{9}$ The authors have direct experience with delegations from Brazil, Cape Verde, and Mozambique visiting the Portuguese Centre for Tax Arbitration in order to assess the advantages of its introduction.

The article is organized as follows. Section 2 presents a literature review on frequent TP litigation issues and international trends in court outcomes; section 3 deals with methodology; section 4 presents an analysis of Portuguese TP arbitration rulings; section 5 highlights policy implications for group managers, TAs, and tax legislators; and section 6 concludes.

\section{Literature Review}

The allocation of profits and losses between the units of a business group, when those units are based in countries with different tax rates, influences the distribution of corporate tax receipts between countries. Consequently, methods for determining the tax base corresponding to each jurisdiction are of considerable importance.
International conventions and national tax laws dealing with group transactions are based on the so-called principle of independence, also known as the 'arm's length rule'. ${ }^{10}$ It implies the obligation to use the same prices in the valuation of transactions between related entities that would be practiced in comparable operations between independent entities.

Although the principle is not complicated in its formulation, it may be quite difficult to apply. Multinational companies are, by the nature of their activities, entities for which the control of transfer prices is challenging and complex. ${ }^{11}$ Economies of scale, often a decisive factor in investments, as well as the weight of intra-group transactions, geographical diversification, internationalization of production processes, ${ }^{12}$ intra-group service operational centres, ${ }^{13}$ and intangible assets ${ }^{14}$ may originate issues for the correct evaluation of transfer prices because they have a significant impact on the comparability process. This is why, in many cases, disputes arise between TAs and taxpayers and, consequently, litigation may follow.

\section{I Motives for Transfer Pricing Litigation}

\section{I.I Comparability Issues}

A core issue in transfer pricing legislation and litigation settings is the comparability of transactions between related parties and similar operations between independent entities. Tavares ${ }^{15}$ states that tax law incorporates economic rules on determining a market price that would imply equilibrium between supply and demand among independent traders. That means the price is that for which an independent, informed, and knowledgeable party would charge for a good or a service. The selection of an international marketing strategy and its impact on transfer pricing involves complex issues of comparability between functions, risks, and return rates that an independent party would accept for performing such functions and taking certain risks. Pereira ${ }^{16}$ emphasizes the difficulties in applying the comparability principle, specifically, the fact that independent firms do not execute a set of transactions that are usually found between related parties and how to quantify synergies arising from intra group operations.

\section{Notes}

See F.S. Câmara, Arbitration as a Means of Resolving Tax Disputes, 54(11) European Tax'n 491 (2014).

See OECD, supra n. 1

11 See P. Matos \& F. de Moura, Portugal, Transfer Pricing L. Rev. (1 June 2018), https://thelawreviews.co.uk/edition/transfer-pricing-law-review-edition-1/1144224/portugal (accessed 16 Apr. 2020)

12 See C. Breia, Internacionalizą̧ão: o desafio dos prę̧os de transferência 31-48 (J. T. Gama coord., Almedina 2013).

13 See P. Alves, Preços de transferência nas prestą̧ões de serviços intra grupo, Masters Dissertation, Faculdade de Direito de Lisboa (2013).

14 See I. F. Melo, Quanto vale uma ideia? A determinação do prȩ̣o de transferência nas operaçöes com ativos intangiveis 111-125 (J.T. Gama coord., Almedina 2013).

15 See T. Tavares, Preços de transferencia e valor de mercado do art. 46 do CIRC 309-317 (J. T. Gama coord., Almedina 2013).

16 See M. F. Pereira, Fiscalidade (Almedina 2015). 
Undoubtedly, the key factor in determining the arm's length price is the comparability of the related party transactions with similar operations that are performed between independent entities. ${ }^{17}$ Comparability involves the analysis of characteristics of goods and services, business strategies, contractual terms, and other relevant features of transactions under appreciation. Internal comparables, when they exist, may exhibit a closer relationship with transactions under review than external comparables.

The Portuguese tax legislation on transfer pricing comparability establishes a broad set of factors that must be taken into consideration. ${ }^{18}$ They are: the characteristics of goods and services; market share, economic, and financial conditions; marketing strategies; performed functions; used assets; and risks taken. As Campos ${ }^{19}$ as well as Martins and $\mathrm{Sá}^{20}$ point out, not only products and services developed by groups are increasingly differentiated, and, therefore, less comparable, but a significant number of intra group transactions is related to unique intangible assets (e.g. patents, trademarks) for which valuation is extremely difficult. The identification of a comparable operation may be a demanding task. ${ }^{21}$

Considering the diversity of elements to be examined when tax auditors test the comparability of operations in a substantial number of situations, TAs and taxpayers have opposing views as to what should be the most appropriate comparable. ${ }^{22}$ In a significant number of cases, TAs opt for internal comparables and are challenged by taxpayers on the basis that those comparables lack robustness given differences on product specification, market segmentation, and the financial conditions of the operation that are not comparable with goods and services that are sold to independent parties. ${ }^{23}$ In other cases, financial transactions occurring between related parties are not easily comparable with similar transactions between independent. Rating issues, cash management practices that are specific for groups, or financial contracting that are not easily ascertained in open markets make financial transactions between related parties a complex issue in tax auditing.
These topics, consequently, are a frequent basis for TP litigation considering the multiple angles that comparability can take.

\section{I.2 The Selected Method}

Another topic that may originate strong divergence between TAs and companies is the method that is chosen to determine the arm's length price. ${ }^{24}$ Tax auditors often select the comparable market price method (with a preference for internal comparables) while taxpayers contend that comparability failures in audit reports deny legal validity to such comparables.

Tax legislation on transfer pricing ${ }^{25}$ following the OECD Guidelines demands that using the comparable market price implies the highest degree of comparability on transacted items, contractual conditions, and functions performed by involved entities. There is a lower level of acquaintance with business operations that are usually presented by tax auditors, relatively to companies' managers. Therefore, it is not difficult to foresee that, when a certain method is selected by the TA, taxpayers will attempt to determine deficiencies in its application in order to deny validity to audit adjustments. ${ }^{26}$

Even when a certain method is accepted by firms and TAs, its application can be a source of litigation. For example, when applying the net margin method, tax auditors may not agree with the selected profit level indicator to determine the net margin. The $\mathrm{OECD}^{27}$ states that only those items directly or indirectly related to the targeted transaction(s) and of an operational nature should be considered in the computation of the profit level indicator.

Additionally, when using samples and margin based methods, the proper adjustment range is another issue that may cause opposition between companies and tax auditors. According to Ernest and Young, ${ }^{28}$ after performing the comparability analysis, auditors tend to make adjustments based on the median of the inter quartile range while taxpayers argue that the first quartile is enough to ensure comparability.

\section{Notes}

17 See Gama, supra n. 4

18 See PT: Art. 63 Corporate Income Tax Code (CITC) and Regulation 1446-C/2001.

19 See D. L. Campos, Preģos de Transferencia e Arbitragem, 67(3) Separata da Revista da Ordem dos Advogados 1007 (2007).

20 See A. Martins \& C. Sá, The Computation of Taxable Income When Accounting Numbers Are Not Reliable: A Note on Presumptions, 60(2) Int'l J. L. \& Mgmt. 543 (2018).

21 A. Martins, The Portuguese Intellectual Property Box: Issues in Designing Investment Incentives, 17(3) J Int'l Trade L. \& Pol'y 86 (2018).

22 See Muhammadi, Ahmed \& Habib, supra n. 2.

23 See S. Padhi \& R. Bal, Transfer Pricing Regulations \& Litigation - A Critical Appraisal based on Tribunal Judgements, 12(1) XIMB J. Mgmt. 57 (2015).

24 See Bradley, supra n. 2.

25 See PT: Regulation 1446-C/2001, Art. 6.

26 See D. Barros \& G. Teixeira, Preços de Transferência e o Caso Português (Vida Económica 2004).

See OECD, supra n. 1 .

28 See Ernst \& Young, Worldwide Transfer Pricing Reference Guide 2015-16 (16 June 2017). 
Additionally, margin based methods are often prone to litigation based on statistical issues. For example, if a certain company that is included in the comparable sample has a negative margin and is considered a statistical outlier, it must be eliminated. If a particular year exhibits non-typical economic conditions, a multi-year average margin should be used.

\section{I.3 Intra Group Services}

Related entities may take advantage of the immaterial nature of services to transfer profits to low tax jurisdictions. These operations may be disguised as payments for intra-group services at inflated prices. For this reason, TAs have been devoting increasing resources to audit these transactions.

According to the OECD, ${ }^{29}$ there are two main issues in the analysis of intra-group services: whether a service was actually rendered and the compliance of the service pricing with the arm's length principle. Considering the immateriality of intra-group services, the beneficiary must prove that a service was provided and that it was properly qualified and quantified. Whether the service that is provided confers a certain benefit to the counterpart that justifies the payment of a price is an important issue. This is described by the OECD $(2017)^{30}$ as the benefit test. Activities that do not provide any benefit will not be considered an intragroup service. This topic is a usual focus of tax auditing. ${ }^{31}$

If an intra-group service was provided, it is necessary to determine whether the price charged, if any, is in accordance with the arm's length principle. Taxpayers must collect the necessary documentation to substantiate the economic and commercial value received for the acquisition of intra-group services and to demonstrate that an independent entity would, in similar circumstances, pay for the services rather than performing them (KPMG, 2017). ${ }^{32}$

\subsubsection{Intangibles}

Intangibles are important sources of value creation and competitiveness for economic groups. ${ }^{33}$ As argued by Beer and Loeprick ${ }^{34}$ 'transfer of intangible ownership or licensing arrangements are thus key areas for transfer pricing valuations, disputes, and are at the focus of ongoing coordination efforts at the international level'.

According to Wright et al., ${ }^{35}$ certain intangibles are often traded generally within multinational groups. Therefore, it is difficult to identify external comparables which hampers the application of the arm's length principle.

Another problem arises when several entities within a group develop intangibles and subsequently use those assets regardless of their contribution to the initial development. In this context, it is quite complex to determine what constitutes an arm's length price for a patent, a trade mark, or a license since direct evidence on the terms and conditions that would have been established by independent companies is minimal or even non-existent. ${ }^{36}$

Intra group transactions with intangibles may lack economic substance, serving only as profit shifting strategies, and the Base Erosion and Profit Shifting (BEPS) Project addressed that issue. Considering these sources of complexity and uncertainty in determining the proper pricing policy, it is not surprising that strong divergence between TAs and taxpayers may occur, consequently followed by litigation.

\subsubsection{Intra Group Financing}

Terms and conditions that are applied to financial transactions between related parties, such as intra-group loans, the provision of guarantees, and cash pooling mechanisms, have been scrutinized by TAs in several jurisdictions. ${ }^{37}$ This is confirmed by Bakker and Levey ${ }^{38}$ who show that, in intra group financing, the evaluation of the arm's length condition is not an easy task. This is not only

\section{Notes}

29 See OECD, supra n. 1.

Io Ibid.

31 See A. Bakker \& M. M. Levey, Transfer Pricing E Intra-group Financing: The Entangled Worlds of Financial Markets and Transfer Pricing (IBFD 2012).

32 See KPMG, Transfer Pricing Considerations for Intragroup Service Transactions, (22 Oct. 2017), https://assets.kpmg.com/content/dam/kpmg/ng/pdf/tax/ng-transfer-pricingconsiderations-for-intragroup.pdf (accessed 16 Apr. 2020).

33 See Y. Brauner, Value in the Eye of the Bebolder: The Valuation of Intangibles for Transfer Pricing Purposes, 28 Va. Tax Rev. 79 (2008).

34 See S. Beer \& J. Loeprick, Profit Shifting: Drivers of Transfer (mis)Pricing and the Potential of Countermeasures, 22(3) Int'l Tax Pub. Fin. 426 (2015).

35 See D. R. Wright, H. A. Keates, J. Lewis \& L. Auten, The BEPS Action 8 Final Report: Comments from Economists, 23(2) Int'l Transfer Pricing J. 99 (2016).

36 See J. Barker, K. Asare \& S. Brickman, Transfer Pricing As A Vehicle In Corporate Tax Avoidance, 33 J. Applied Bus. Res. 9 (2015).

37 See Chand, supra n. 7.

38 See Bakker \& Levey, supra n. 31. 
because of the intricate configuration of many financial operations but especially because there are no objective guidelines and legislation for the treatment of practical questions that arise when determining arm's length prices (e.g. on the methodology to be applied in the assessment of credit risk). The existing guidelines are somewhat ambiguous and susceptible of being arbitrarily interpreted. ${ }^{39}$

For example, when analysing the transfer price of an intra-group loan, it is important to check the borrower's rating status in order to assess whether it could obtain an equal or similar debt from an independent creditor. ${ }^{40}$ The arm's length interest rate for the transaction, taking into account its specific characteristics, specifically, the date, the repayment period, the borrower's credit risk and its level of indebtedness, the associated collateral, the interest rate, the debtor's activity sector, and the currency in which the transaction was agreed are considered relevant features for analysing TP in financial transactions.

\section{I.6 Interim Conclusion}

The authors can conclude that, according to the literature, the most common motives for transfer pricing litigation are the following:

1) Issues arising from the comparability issue. Corporate assets, functions, and risks are crucial in this analysis. In many cases, tax auditors do not have the time and technical knowledge to produce solid audit reports with a substantiated analysis of comparability. On the other hand, companies and tax lawyers attempt to ascertain any type of discrepancies in order to challenge TP adjustments based on deficiencies in the comparability analysis.

2) Methods used in TP reports. The comparable market price (CMP) is often used by TAs when firms have transactions with related and independent parties. Companies regularly question the appropriateness of the CMP when economic, market, contractual, or financial arrangements are not similar. Additionally, accounting indicators are often challenged when using margin based methods. Samples are also a disputed topic when adjustments are made based on the inter quartile range, and potential outliers may influence results.
3) Prices used in intergroup services and the economic and accounting rationale for computing such prices that can be used for profit shifting strategies are commonly litigated. Given the immateriality of services, cost imputation methods present a significant degree of subjectivism. Intangibles are also prone to originate tax disputes in TP. They often imply an intergroup allocation of assets, costs, and revenues that are questioned by TAs on abusive tax planning grounds.

4) Intragroup finance and the level of interest rates are another fertile ground for TP litigation. Finding a true comparable market rate considering the functions and risks in financing operations is quite complex and often produces different views between firms and tax auditors.

\subsection{Transfer Pricing Court Outcomes: International Trends}

In the international judicial scene, $\mathrm{TP}$ is also a contentious issue. ${ }^{41}$ TAs are pressed to find revenue, and companies are prone to litigate TP cases. ${ }^{42,} 43$

According to Mudigonda et al. ${ }^{44}$ who are focusing on the Asia Pacific region, India has updated its TP regulations, making its application more attuned to OECD's Guidelines. They also mention that a clear majority of rulings (around 60\%) favour taxpayers. In Japan, there are comparatively fewer TP cases because of a generalized use of the Mutual Agreement Procedure which may settle a TP dispute before litigation occurs. Nonetheless, when litigation happens, taxpayers have a higher rate of success than TAs.

China has also updated its TP auditing system, and intangibles have been gaining visibility as a litigation area in its TP application. Selecting audit samples and monitoring important intra group transactions and rates of return have produced better targeted audits.

According to Deloitte, ${ }^{45}$ Indian courts have been issuing rulings primarily favouring taxpayers. TAs routinely appeal, which is criticized by increasing costs and uncertainty when lower courts issue clear decisions. The information technology (IT) sector transactions are usually challenged by tax audits based on the comparability principle. Courts find it quite complex to apply considering IT's specific type of assets and transactions. When in

\section{Notes}

39 See S. Greil \& D. Schilling, Cross-Border Financial Transactions and Arm's Length Interest Rates: A Two-Step Approach, 44(11) Intertax 802 (2016).

40 See Bakker \& Levey, supra n. 31

41 See V. Mudigonda, E. Kuo \& G. Thomas, Recent Developments in Transfer Pricing in Asia Pacific, Int'l Tax Rev. 1(22) (2016).

42 See R. Avi-Yonah, Back to the Future? Medtronic and the Future of Transfer Pricing, 43 Int'l Tax J. 33 (2016).

43 See M. E. Palombo, What the Italian Transfer Pricing Cases Mean, 14 Int'l Tax Rev. 1 (2003).

44 See Mudigonda, Kuo \& Thomas, supra n. 41

45 See Deloitte, Transfer Pricing Disputing Trends (2015) 
doubt, they decide by validating taxpayers' positions. Indian higher courts have also paid attention to notorious international cases in order to improve reasoning behind important cases. Common litigation issues are: selecting appropriate comparable companies, computation of profit level indicators, selecting the most appropriate TP method, and intergroup services.

In the United States and according to Avi-Yonah, ${ }^{46}$ multinational companies face significant scrutiny related to the accuracy of prices used in intra group transactions. One of the most investigated areas is the pricing of intangibles. The Internal Revenue Service regularly audits and litigates TP cases for which taxpayers have enjoyed important victories in high-profile transfer pricing cases. Some recent notable cases in which companies prevailed include Amazon ${ }^{47}$ and Medtronic. ${ }^{48}$

In Italy, Palombo ${ }^{49}$ offers evidence that Italian TAs were often on the unsuccessful side in TP court cases. The author ascribes this outcome to the insufficient consistency of TP audits and the unpreparedness of Italian tax auditors for addressing such novel and complex fiscal issues. She notes, however, a willingness to learn from past failures and to improve tax auditing.

\section{Methodology}

The methodology employed in this article draws on three aspects. Firstly, as the literature review reveals the difficulties of TAs in TP litigation, statistical evidence from arbitration court cases is presented, confirming that the documented trend is also observed in Portugal. The thirty-two cases presented include all of the TP arbitrated cases in Portugal between 2012 and 2017.

Secondly, selected case decisions will be presented in order to highlight disputed areas such as comparability, TP methods, or financial operations. These rulings illustrate how several cases were addressed by tax arbitrators. They also provide materials for the third prong.

Thirdly, the legal interpretative method will be applied to the analysis of court rulings and emphasize the specifics of TP legal complexities, particularly in litigation settings.
As stated by Bell, ${ }^{50}$ law is an applied discipline and, as such, includes a reflection on its purposes and how they are achieved by the actions of litigants and courts. Courts must deal with analytical reasoning and the specific features of the cases that are brought to their judgement. In the case of transfer pricing litigation, legal texts, OECD Guidelines (as soft law), precedents, international trends, and emblematic cases are a set of diverse sources to achieve what is thought to be the best solution in a tax domain that is plagued by ambiguous concepts (e.g. comparability, reasonable adjustments in inter quartile ranges).

As previously noted, usual motives for TP litigation involve accounting, financial, statistical, and legal concepts. Many of them are broadly defined in law, and courts must contend with a certain margin of interpretation. For example, the ever present comparability principle requires an analysis of markets, functions, assets, and risks that are generally difficult to identify and compare. On the other hand, tax auditors, when challenging firms' use of TP, must also present consistent reasoning and evidence that prices are not appropriate. As stated by McCruden $^{51}$ :

If legal academic work shows anything, it shows that an applicable legal norm on anything but the most banal question is likely to be complex, nuanced and contested. Law is not a datum; it is in constant evolution, developing in ways that are sometimes startling and endlessly inventive.

Finally, a case analysis will also be used as a basis for some recommendations to TAs, corporate managers, and tax legislators.

\section{The Portuguese case: evidence of TRENDS IN TP ARBITRATION RULINGS}

\section{I The Portuguese Transfer Pricing Tax Rules: A Brief Overview}

Article 63 of the Portuguese Corporate Income Tax (CIT), on transfer pricing, establishes that:

\section{Notes}

46 See Avi-Yonah, supra n. 42

47 The case centred on a cost-sharing arrangement that Amazon had entered into with a European affiliate. The Internal Revenue Service (IRS) assessed deficiencies against the company of over USD 230 million claiming that the buy-in payment and cost allocations under the agreement had not been determined at arm's length. The tax court rejected the IRS's transfer pricing adjustments and ruled in favour of Amazon.

48 The case involved a US medical device manufacturer and royalty payments received from its Puerto Rico-based subsidiary. Medtronic Puerto Rico Operations (MPROC) was responsible for manufacturing various medical devices. With regard to these products, Medtronic was responsible for clinical studies, research and development, and quality control, among other things. MPROC was also responsible for business profitability, quality compliance, innovation, and supplier relationship management. Medtronic and MPROC entered into licence agreements for the intangible property that was necessary to manufacture and sell the devices and leads. In exchange for these rights, Medtronic received a $29 \%$ royalty on the sales of devices and a $15 \%$ royalty on the sale of leads. The IRS argued that Medtronic should have received higher royalties from MPROC The tax court sided with Medtronic, finding that the taxpayer's method was appropriate and that the IRS's adjustments were arbitrary, capricious, and unreasonable.

49 See Palombo, supra n. 43.

50 See J. Bell, Legal Research and the Distinctiveness of Comparative Law, in: Methodologies of Legal Research - Which Kind of Method for What Kind of Discipline? $155-175$ (M. Van Hoecke ed., Hart Publishing 2013).

51 See C. McCrudden, Legal Research and the Social Sciences, 122 L. Q. Rev. 632, 648 (2006). 
in commercial operations, including transactions of goods or services, as well as financial transactions carried out between a firm and any other entity, which is in a situation of a special relationship with the former, terms and conditions substantially identical to those contracted between independent entities, in similar transactions, should be practiced.

Regulation 1446-C/2001, adhering to the OECD Guidelines, establishes methods that can be used to ensure comparability. Additionally, this regulation rules on the definition of related parties, advance price agreements, and the documentation and content that a TP report must exhibit. Methods for checking comparability include the comparable uncontrolled price method, the resale price method, the cost plus method, the profit split method, and the transactional net margin method. Other methods are still admissible when none of the above guarantees the highest degree of comparability.

From this brief synthesis and considering the range of factors entering the comparability analysis, interpretative issues and subsequent disputes can follow. Additionally, the decision for the most reliable method is also an area fraught with difficulties for taxpayers and TAs.

\subsection{Basics of Tax Arbitration in Portugal}

Tax arbitration was established in Portugal in 2011. Conditions prevailing in state courts with extended time spans for reaching a decision called for alternative resolution mechanisms. A comparison between Portuguese tax judicial courts and arbitration courts - drawing on Câmara $^{52}-$ is presented in Table 1.

Table 1 A Comparison Between Judicial and Arbitration Tax Courts in Portugal ${ }^{53}$

\begin{tabular}{cll}
\hline Main Topics & Tax Judicial court & $\begin{array}{l}\text { Tax Arbitration } \\
\text { Court }\end{array}$ \\
\hline Claim value & No limit & $\begin{array}{l}\text { Max. EUR 10 } \\
\text { million }\end{array}$ \\
$\begin{array}{c}\text { Basis for court } \\
\text { decisions }\end{array}$ & Tax law & $\begin{array}{l}\text { Tax law; no } \\
\text { fairness or } \\
\text { equity based } \\
\text { rulings allowed }\end{array}$ \\
$\begin{array}{c}\text { Time limit for } \\
\text { decision }\end{array}$ & $\begin{array}{l}\text { Average three } \\
\text { years on first } \\
\text { instance }\end{array}$ & Max. six months \\
\hline
\end{tabular}

\begin{tabular}{|c|c|c|}
\hline Main Topics & Tax Judicial court & $\begin{array}{l}\text { Tax Arbitration } \\
\text { Court }\end{array}$ \\
\hline $\begin{array}{l}\text { Possibility of } \\
\text { appeal }\end{array}$ & yes & $\begin{array}{l}\text { No, as a rule. } \\
\text { Exceptionally } \\
\text { yes if constitu- } \\
\text { tional issues } \\
\text { emerge or if a } \\
\text { consolidated jur- } \\
\text { isprudence trend } \\
\text { is not followed } \\
\text { by arbitrators }\end{array}$ \\
\hline $\begin{array}{l}\text { Number of } \\
\text { judges }\end{array}$ & 1-first instance & $\begin{array}{l}\text { One to three, } \\
\text { depending on } \\
\text { the value of the } \\
\text { claim. If claim } \\
\text { is over EUR } \\
60.000 \text {, three } \\
\text { arbitrators must } \\
\text { intervene }\end{array}$ \\
\hline $\begin{array}{l}\text { Judges/arbitra- } \\
\text { tors' expertise }\end{array}$ & $\begin{array}{l}\text { Reduced, initi- } \\
\text { ally; grows with } \\
\text { practice }\end{array}$ & $\begin{array}{l}\text { Specialization in } \\
\text { different areas } \\
\text { (Tax law, } \\
\text { accounting, } \\
\text { finance) }\end{array}$ \\
\hline $\begin{array}{l}\text { Average number } \\
\text { of cases per } \\
\text { year }\end{array}$ & Several hundred & $\begin{array}{l}\text { up to ten; some } \\
\text { chairpersons } \\
\text { may have more }\end{array}$ \\
\hline Independence & yes, career judges & $\begin{array}{l}\text { yes, under scru- } \\
\text { tiny from } \\
\text { Centro de } \\
\text { Arbitragem } \\
\text { Administrativa } \\
\text { (CAAD), tax- } \\
\text { payers and TA }\end{array}$ \\
\hline
\end{tabular}

Arbitration courts have a more limited scope in terms of claim values and appeal possibilities that are more restricted. The primary advantages of arbitration courts may be stated as: the length of time in which a decision must be reached; the possible multidisciplinary composition of the court when cases present legal, accounting, and economic issues and justify a broader panel of arbitrators; the more informal nature of procedural steps; and extensively using an information technology infrastructure for all procedural requirements. However, arbitration usually implies greater costs for litigants. The potential for tax arbitration in Portugal is significant given the enormous backlog in state judicial tax courts. For companies requiring a more rapid resolution of disputes, it is considered as an appropriate route. Given that TP cases often arise in multinational companies, a significant number of these

\section{Notes}

52 See Câmara, supra n. 6.

53 See A. Martins, Witness Testimony in Transfer Pricing Litigation, 1 Int'l Transfer Pricing J. 32 (2017). 
cases is being brought under arbitration courts. Rulings are publicly available on the web site of the Arbitration Centre (CAAD). ${ }^{54}$

\subsection{TP Cases, Litigation Motives and Decision Trends in Portuguese Arbitration Courts from 2012 to 2017}

This section presents statistical evidence of all TP arbitration decisions in the analysed period and explores a number of selected rulings pertaining to each litigation topic. Section 4.4 will present a discussion of legal and economic issues related to the arbitration scenario.

Table 2 illustrates that Portuguese arbitration courts, in the period of 2012-2017, decided all of the TP cases under litigation as mostly in favour of taxpayers. Thus, the international trend that was previously documented is also observed in Portugal.

Table 2 Arbitration Rulings in TP Cases in Portugal

\begin{tabular}{lll}
\hline TP Cases & Number & $\%$ \\
\hline $\begin{array}{l}\text { Decision favourable to } \\
\text { taxpayers }\end{array}$ & 29 & 90,6 \\
$\begin{array}{l}\text { Decision favourable to } \\
\text { TA }\end{array}$ & 3 & 9,4 \\
Total & 32 & 100 \\
\hline
\end{tabular}

Source: www.caad.org.pt

Table 3 presents data regarding the amounts in dispute.

Table 3 Amounts in Dispute $(€)$

\begin{tabular}{llll}
\hline Case & Amount & $607 / 2014-\mathrm{T}$ & $232.517,19$ \\
\hline 76/2012-T & $47.3151,76$ & $660 / 2014-\mathrm{T}$ & $894.220,16$ \\
$55 / 2012-\mathrm{T}$ & $1.333 .869,13$ & $644 / 2014-\mathrm{T}$ & $923.497,45$ \\
91/2012-T & $658.206,55$ & $711 / 2014-\mathrm{T}$ & $15.583,57$ \\
$134 / 2012-\mathrm{T}$ & $206.535,65$ & $716 / 2014-\mathrm{T}$ & $911.356,14$ \\
$112 / 2013-\mathrm{T}$ & $685.391,37$ & $844 / 2014-\mathrm{T}$ & $153.892,69$ \\
$130 / 2013-\mathrm{T}$ & $1.300 .562,19$ & $109 / 2015-\mathrm{T}$ & $324.955,39$ \\
$160 / 2013-\mathrm{T}$ & $155.345,13$ & $281 / 2015-\mathrm{T}$ & $461.772,07$ \\
$145 / 2013-\mathrm{T}$ & $1.309 .646,93$ & $423 / 2015-\mathrm{T}$ & $3.189 .298,00$ \\
230/2013-T & $352.394,56$ & $609 / 2015-\mathrm{T}$ & $339.394,43$ \\
\hline
\end{tabular}

\begin{tabular}{llll}
\hline Case & Amount & $607 / 2014-\mathrm{T}$ & $232.517,19$ \\
\hline 146/2013-T & $1.795 .200,88$ & $559 / 2015-\mathrm{T}$ & $120.222,74$ \\
254/2013-T & $205.866,26$ & $733 / 2015-\mathrm{T}$ & $8.168 .002,29$ \\
$148 / 2013-\mathrm{T}$ & $1.018 .316,93$ & $762 / 2015-\mathrm{T}$ & $1.278 .260,7$ \\
$181 / 2014-\mathrm{T}$ & $125.000,00$ & $267 / 2016-\mathrm{T}$ & $779.880,49$ \\
$101 / 2014-\mathrm{T}$ & $368.175,77$ & $75 / 2016-\mathrm{T}$ & $110.234,74$ \\
300/2013-T & $40.221,54$ & 378/2017-T & $95.426,99$ \\
275/2014-T & $465.486,56$ & TOTAL & $28.491 .886,25$ \\
\hline & & &
\end{tabular}

The total amount in dispute for the entire period was EUR 28.491.886,25. TAs successfully prevailed in 275/2014-T, 423/2015-T, and 609/2015-T. These three cases represent $14,01 \%$ of the total litigated amount which is not very different from the percentage of cases with a positive outcome for the TAs $(9,4 \%)$.

A possible explanation for these results, quite unfavourable to the TAs, is that litigated cases are those that taxpayers feel are insufficiently substantiated by tax auditors. Nonetheless, either in judicial state courts or in arbitration courts, the Portuguese TAs lose approximately $60 \%$ of all tax cases. ${ }^{55}$

Another possible explanation for these litigation outcomes is that TAs are pressed with reaching performance metrics in terms of income tax adjustments (not effective cash receipts). Groups of companies have related party transactions with substantial amounts of money in revenues and expenses, and TAs may find transfer pricing a special target for tax adjustments. A problem of selection bias for court outcomes may also be derived from a selection bias in tax auditing activities.

Moreover, it must not be overlooked that, before reaching the court stage, a tax audit report usually has two appeals: first to the auditing service when the taxpayers highlight inconsistencies in TP auditing arguments and an additional appeal to the highest ranking officer in the TAs' organizational structures. Hence, several opportunities arise for improving the quality of tax auditing reports. The fact that court decisions are so unfavourable against the TAs indicates that these mechanisms are probably not as efficient as they should be.

Tables 4-6 depict the core issues related to all cases and how courts decided. The comparability concept, the selected TP methods, and the legal grounds for applying TP regulations are major issues.

\section{Notes}

54 See Centro de Arbitragem Administrativa, www.caad.org.pt (accessed 16 Apr. 2020) and the 'Jurisprudence' area where all tax cases have their rulings published (omitting the actual name of litigants)

55 See S. Correia \& A. Martins Prȩ̣os de transferência, litigância e arbitragem fiscal, (Petrony 2018). 
Table 4 Arbitration Cases Related to the Comparability Concept

\begin{tabular}{lll}
\hline Cases & Core Issue & Court Decision \\
\hline 55/2012-T 160/2013-T & Comparability & For the taxpayer \\
230/2013-T 91/2012-T & TAs using internal & TAs approach did \\
145/2013-T 146/2013-T & comparables and & not follow the \\
148/2013-T 254/2013-T & applying the com- & comparability \\
300/2013-T 607/2014-T & parable market & analysis required \\
644/2014-T 660/2014-T & price (CMP) & by law \\
711/2014-T 716/2014-T & Taxpayers using & (markets, strate- \\
844/2014-T 559/2015-T & external compar- & gies, assets, func- \\
733/2015-T 762/2015-T & ables or margin & tions, risks, \\
75/2016-T; 378/2017-T & based methods & contractual terms, \\
& because internal & etc.) \\
& comparability is not & \\
& considered as & \\
& appropriate. & \\
\hline
\end{tabular}

Source: www.caad.org.pt

As Table 4 shows, arbitration courts ruled for taxpayers in twenty cases $(62,5 \%$ of total) due to the inconsistent application of the comparability principle by the TAs. If TAs discover deficiencies in TP reports and make adjustments, then the burden of proof to find comparable operations to sustain an arm's length analysis becomes the responsibility of tax auditors. Their analysis must address complex issues such as functions, assets, risks, and business strategies performed by the company under analysis and the entities that are selected as comparables. ${ }^{56}$

In Case No. 844/2014-T, according to the TA, the external comparables used by the firm were not appropriate for analysing if the conditions that were practiced in related party transactions were the same that would be established among independent entities since there were significant differences in comparability factors. However, according to the taxpayer, it was impracticable to use internal transactions as comparables. They represented transactions of the same products with independent entities but were not similar, adhering to the comparability legal requirements, and it was not possible to make sufficiently reliable adjustments to eliminate all of the relevant differences. After examining the adjustments made by the TA, the court concluded that they were not sufficient to eliminate the differences in comparability. Thus, an internal comparable was inappropriately exploited by tax auditors.

In Case No. 733/2015-T, the conflict focused on the comparable operations that should be selected to set arm's length prices, particularly whether external comparables (the company's option) or internal (the TA's choice) should be used. The court agreed with the position of the TA that external comparables used by the firm did not ensure the highest degree of comparability. Therefore, by not accepting those comparables, the TA acted in accordance with the TP rules. However, the court ruled that the internal comparable used by tax auditors did not guarantee the highest degree of comparability between the related operation and the independent one considered as a benchmark due to the existence of deficiencies in the analysis of the legal comparability factors.

In Case No. 559/2015-T, tax auditors did not address one of the fundamental pillars on which the TP tax regime is based - the independent nature of the operation considered as being comparable. In applying the adopted method (CMP) to assess compliance with the arm's length principle, the transaction that the TA considered to be comparable did not reflect an operation performed between independent parties but rather a related party transaction. As the court stressed, these operations could not be comparable. This case was regarding a trade mark transaction and illustrates how difficult it may be to find independent comparables in operations involving intangible assets.

Table 4 shows that, similarly to international trends, Portuguese arbitration courts rarely validate alternative comparability analyses performed by $\mathrm{TAs}^{57,}{ }^{58}$ On the other hand, it must be emphasized that, considering the range of comparability issues, it is not difficult for experienced tax lawyers and consultants to find at least one inconsistency in a TA's analysis. The inherent complexity of the issue and the significant probability of a comparability factor (e.g. market strategy, functions performed) being open to question, even in a rigorous tax audit, all converge to court decisions that favour taxpayers. ${ }^{59}$

Closely associated with the comparability principle is the divergence between taxpayers and TAs regarding the most effective method to base TP adjustments. Table 5 depicts court decisions on this topic. ${ }^{60}$

Table 5 Arbitration Cases Related to TP Selected Methods

\begin{tabular}{lll}
\hline Cases & Core Issue & Court Decision \\
\hline $145 / 2013-\mathrm{T}$ & $\begin{array}{l}\text { Methods used in } \\
\text { TP compliance } \\
\text { proof } \mathrm{TAs} \text { show }\end{array}$ & $\begin{array}{l}\text { For the } \\
\text { taxpayer }\end{array}$ \\
\hline
\end{tabular}

\section{Notes}

56 See Loeprick, Cooper, Fox \& Mohindra, supra n. 5.

57 See Mudigonda, Kuo \& Thomas, supra n. 41.

58 See Palombo, supra n. 43.

59 See M. M. Levey \& S. C. Wrappe, Transfer Pricing: Rules, Compliance, and Controversy (Wolters Kluwer 2013).

60 Four of the five cases in Table 5 also appear in Table 4. That signifies that both issues (comparability and selected TP method) were intertwined and closely linked as core arbitration topics in these cases. 


\begin{tabular}{|c|c|c|}
\hline Cases & Core Issue & Court Decision \\
\hline $\begin{array}{l}148 / 2013-\mathrm{T} \\
181 / 2014-\mathrm{T} \\
762 / 2015-\mathrm{T}\end{array}$ & $\begin{array}{l}\text { preference for the } \\
\text { CMPTaxpayers, } \\
\text { using margin } \\
\text { based methods, } \\
\text { argue that com- } \\
\text { parability issues } \\
\text { do not allow the } \\
\text { CMP }\end{array}$ & $\begin{array}{l}\text { The CMP } \\
\text { demands the } \\
\text { highest degree } \\
\text { of comparabil- } \\
\text { ity that was } \\
\text { not suffi- } \\
\text { ciently sup- } \\
\text { ported by tax } \\
\text { audits } \\
\text { adjustments. }\end{array}$ \\
\hline
\end{tabular}

Source: www.caad.org.pt

As seen in Table 5, in five cases, arbitration courts analysed TAs' preferences for the CMP. All firms had transactions with non-related parties, however, courts determined that the degree of comparability with related party operations was not enough to validate the CMP.

In Cases $n^{\circ}$ 145/2013-T, 146/2013-T, 148/2013-T and $762 / 2015-\mathrm{T}$, firms argued that the cost plus method, complemented by net operating margin method, were the most appropriate for determining arm's length conditions. They rejected the application of the comparable market price on the grounds that it was impracticable due to significant differences in comparability factors in the operations being analysed. The TA did not agree with either the assumptions upon which the methods adopted by firms were based nor with the arguments presented in TP files to justify possible differences between the prices charged on the related transactions compared to the prices applied in unrelated transactions. Tax auditors considered that the comparable market price guaranteed the highest degree of comparability between the operations under analysis. The courts accepted the arguments of companies, rejecting the CMP since it is the most demanding method, and the TAs failed in analysing all of the elements of comparability that should be applied.

In Case No. 181/2014-T, the TA intended to apply the CMP in order to determine the arm's length price for remuneration from a parent company to one of its administrators who was performing management functions in an related entity in representation of the parent's interests. According to the TA, independent companies would not be willing to bear the cost of the remuneration of a director whose duties were performed for another entity and, therefore, an adjustment was made to the tax base. In its assessment, the court pointed out that it was a regular practice that could be performed with advantages for the parent and was also usual in the management context of other groups.

Regarding the way in which the tax base was adjusted by the tax auditor, the court stated that the CMP was not the most appropriate for the situation since it involved operations only conducted within an economic group and, therefore, unparalleled in the context of independent entities. The TA should have used a more appropriate and compliant method for this type of operation but decided to apply the CMP to a situation for which no comparability factors allowed its use.

Courts denied legal validity to adjustments computed by TAs by stating that the burden of proof on the comparability issue was not fulfilled in tax audits. A rigorous screening by the senior management of TAs, also taking into consideration judicial precedent, could have reduced disputes.

Table 6 presents data on decisions about legal grounds for litigation.

Table 6 Arbitration Cases Related to Legal Grounds for Litigation

\begin{tabular}{|c|c|c|}
\hline Cases & Core Issue & Court Decision \\
\hline $\begin{array}{l}\text { 76/2012-T } \\
134 / 2012-\mathrm{T} \\
112 / 2013-\mathrm{T} \\
130 / 2013-\mathrm{T} \\
101 / 2014-\mathrm{T} \\
281 / 2015-\mathrm{T} \\
267 / 2016-\mathrm{T}\end{array}$ & $\begin{array}{l}\text { Legal grounds for } \\
\text { the application TP } \\
\text { tax regime } T \text { Ts } \\
\text { arguing that TP } \\
\text { rules apply to } \\
\text { certain operations } \\
\text { Taxpayers } \\
\text { arguing that } \\
\text { operations are } \\
\text { outside the scope } \\
\text { of } T P \text { tax rules }\end{array}$ & $\begin{array}{l}\text { For the taxpayer } \\
\text { TAs did not } \\
\text { present adequate } \\
\text { argumentation } \\
\text { regarding the } \\
\text { application of } \\
\text { TP rules }\end{array}$ \\
\hline
\end{tabular}

Source: www.caad.org.pt

In seven cases lost by the TAs, courts found that auditors erroneously applied TP regulations. For example, audits requalified non-onerous financial operations as remunerated loans and made adjustments based on a presumed interest rate. Moreover, a contract qualified an operation in a certain manner, and tax auditors redefined contractual terms in order to bring operations under TP regulations by using a 'substance over form' approach. In all of these cases, courts determined that tax auditors overextended the application of TP regulations and decided in favour of firms.

In Case No. 130/2013-T, the TA stated that a company sold a portion of shares held in another entity to one of its shareholders in which the aforementioned shareholder was the majority owner. The price was deemed higher than the amount charged in an independent transaction. Therefore, the arm's length principle was not respected. The TA did not correct the price for the difference to the market value but rather requalified the amount that it considered to be above the market price of shares as a dividend. This amount was regarded as constituting taxable capital income in the personal tax of the owner, and auditors made an additional assessment of the shareholder's tax due. The taxpayer challenged the manner in which the TA applied the TP regime, arguing that it does not allow adjustments to personal taxation except in situations when individuals conduct a business or professional activity under the regular accounting regime, which was not the case. 
As stated by the court, Article 32 of the personal income tax mandates that rules of the Corporate Income Tax Code (CITC) apply in the determination of business and professional income for individuals. That means the scope of the TP regime is limited to the determination of the income of these taxpayers. It cannot be applied to the determination of an individual's capital income.

In Cases 101/2014-T, 281/2015-T, and 267/2016-T, the TA did not challenge the price that was charged for the purchase and sale of shares between related entities but denied validity to a contractual clause. In particular, this was related to the clause allowing the deferral of the payment of the agreed price without charging interest as a form of compensation. For the TA, the deferrals meant free financing granted by the seller to the related entity. Therefore, using the CMP and applying it to the mentioned transactions, the TA qualified the financing arrangement as if it was negotiated with an independent entity (e.g. a bank) to which interest would be charged.

From the perspective of companies, the TP regime should not be applied to this situation. It does not allow the legal form of an operation to be changed as if a fictionalized operation was quantified. In the view of firms, tax auditors confused the adjustment of the terms and conditions of the operation with the requalification of the operation. This option is only permitted by the application of the general anti-abuse clause (GAAC).

According to the court, the operation that tax auditors should have considered was the transaction of the shares and not a financing arrangement. Moreover, it is not possible to apply the TP rules to a specific contract clause. In the court's opinion, the way for the TA to consider the existence of a financing operation would be to disregard the purchase and sale of shares that were effectively transacted and the requalification of the operation through the application of the GAAC. The TA could eventually call into question the effectiveness of the purchase and sale agreement by arguing, for example, that its intended purpose was to conceal a genuine financing contract to (abusively) reduce taxes. However, this was not the legal path followed by tax auditors. Consequently, the TP rules were erroneously applied to the fictionalized financing arrangement.

The three cases won by the TA (see Table 2) relate to the methods that were used ${ }^{61}$ and to the arm's length range that is acceptable in the net margin method. ${ }^{62}$ In Case No 275/2014-T, tax auditors considered that the price for which a firm acquired shares from its individual shareholders was not at arm's length. As unlisted shares, the TA determined a TP adjustment through the mechanism provided for in Article 15 of the Stamp Duty Code. Tax auditors concluded that the firm acquired shares for a higher amount than their market price. This excess originated a capital gain that was not subjected to taxation at the personal level. Therefore, the TA disregarded part of the exempted individual income. The company argued that, in addition to the inadequate method adopted by the TA to determine the value of the shares, it was outside its legal purpose since the mentioned stamp duty code article applies to non-onerous transactions. The market value of shares derived from the formula inserted in the Stamp Duty Code was also not established in any income tax law and did not follow from financial standard valuation methods. Thus, it could apply to transfer prices. ${ }^{63}$

According to the court's assessment, the method adopted by the TA to determine the arm's length price of shares, although not the most appropriate, was nevertheless acceptable. Since shares were not listed on the stock exchange, this was the only criterion established in a legal code to determine the value of shares. For this reason, the court found no reason to exclude its application in transfer pricing.

\subsection{An Analysis of Court Rulings: The Legal and Economic Complexity in TP}

The authors' analysis of all of the TP arbitrated cases shows that the Portuguese TAs have a modest success rate. It is believed that, at the core of this outcome, there are issues related to the erroneous application of the comparability principle. Tax law establishes that goods and services' characteristics, market conditions, business strategies, contractual terms, functions performed, and risks assumed are core comparability factors. ${ }^{64}$ Doctrinal sources place considerable emphasis on the analysis of such factors in TP audits. ${ }^{65}$

Transfer pricing tax legislation has an overriding goal: avoiding prices being manipulated by firms engaging in profit shifting strategies. Prices are determined by market conditions, and two prices are comparable if the factors that influence them are subjected to a comparability analysis.

If a TP audit significantly changes the tax base of a company by reconstructing prices then, considering the principle of real or effective income taxation, taxpayers must be confident that comparability tests imposed by law are verified by courts. Additionally, if an economic rationale

\section{Notes}

61 PT: Cases 275/2014-T and 423/2015-T, in which the TA successfully challenged methods used by taxpayers.

62 PT: Case 609/2015-T, in which the TA successfully argued for the median of the range of comparable firms.

63 See A. Martins, Small Businesses, Share Buybacks, Tax Auditing and the Use of Valuation Methods: An Analysis of the Portuguese Case, 14(1) J. Applied Accounting Res. 74 (2013).

64 See Gama, supra n. 4

65 See Pereira, supra n. 16. 
is presented in a tax audit to modify prices and margins, then courts must subsequently proceed to critically scrutinize economic factors such as market strategies, financial conditions, and product similarities. The simple fact that a firm trades with related and independent parties does not automatically imply that an internal comparable is at hand, as the TA often assumes.

Can it be concluded that, in comparability terms, the legal text puts the TA in an unsustainable position? That is not the authors' view given situations when TAs have succeeded in TP cases. Some well substantiated and documented TP audit reports successfully faced judicial challenge. Additionally, two additional factors explaining the low success rate for the TAs may be ventured. Firstly, tax auditors' annual performance reviews are based on adjustments to taxable revenue and not the final outcome of litigation. Secondly, for a tax auditor, no matter his experience, the knowledge of a company business is usually lower or less comprehensive in comparison with a firm's managers.

Regarding selected TP methods, tax audits often exhibit a marked preference for the CMP. On the other hand, firms contend that it demands the highest level of comparability and, therefore, utilize margin-based methods. On a conceptual level, it is true that the CMP works through a direct comparison of prices while margin based methods depend on an indirect comparison of economic profitability to derive arm's length conditions. The latter may experience lower economic rigour but produce TP adjustments and allow a judicial analysis with a degree of value judgment (within the legal admissible range) that are, in many circumstances, more attuned to a non-exact tax topic such as TP.

When employing margin based methods, the comparison of company's economic and financial characteristics is taken as a proxy for the similarity of pricing conditions and. if the tested party falls within the margin range, it is considered as an indicator that transactions are conducted respecting the independence principle. What the arbitration rulings generally show is that TAs' preference for the CMP tends to disregard that this option implies that differences in product specifications, markets conditions, the financial side of transactions, and other comparability factors are nonexistent or minimal.

Another issue that court rulings highlight is that TAs cannot use TP legal rules as if they are a general anti abuse clause. In some cases, tax auditors requalified operations or presumed that other transactions occurred and taxed them according to a new legal configuration. Courts have, correctly, carefully scrutinized this auditing behaviour and ruled it as illegal. In fact, the Portuguese tax system contains a GAAC that can be applied for the purpose of requalifying operations. TP rules, however, were designed for other purposes.

Regarding financial operations, particularly TP share valuation, the Stamp Duty Code, indeed, has a formula for computing share values. Legally, 'other methods' can be used in TP if no other method produces a reliable approximation to market values. It is doubtful if, given the financial data of a company, discounted cash flows (DCF) cannot be used. The stamp duty formula equates share values with the sum of equity book value plus the present value of future estimated profits. This is quite different from DCF methods, which is the standard commonly accepted by financial theory to produce a proxy of market value.

In Case 423/2015-T, the conflict centred around two issues: the net margin method was used and a comparable firm was deemed an outlier by the TA. Additionally, the TA argued that, even if the outlier was eliminated, some comparability issues were still left unresolved in the adjusted sample. Thus, the tax correction was made to the interquartile range and not to the minimum value in the sample.

Article 4 of Regulation 1446-C/2001 states:

If, in the application of a method, the use of two or more comparable related operations, or the application of more than one method considered to be equally appropriate, results in a range of values which ensures a reasonable degree of comparability, no adjustment is necessary if the relevant conditions of the related transaction, in particular price or profit margin, fall within that range.

This rule is quite relevant. It indicates that, if a range of values is achieved that ensure a reasonable degree of comparability, and the margin or the price of the related entity falls within that range, then no adjustment is required.

In this specific case, the degree of comparability appeared to be questionable. Some sampled companies did not exhibit a degree of identity or proximity with the plaintiffs activity, and a significant degree of doubt remained about the actual level of comparability of the sample in general. In this case, doctrinal sources are important. The OECD recommends the interquartile range or the median as valuable criteria to quantify adjustments when, after a deep comparability analysis, there is still some uncertainty.

Briefly, since TP law omits the (formulaic) terms of the quantification of adjustments, its implementation can be made on the basis of several statistical procedures when comparability issues are still open to question, provided that the adjustments are properly justified. The court sided with the TA's arguments. 
To conclude, the authors' evidence confirms the findings of Mudigonda et al., ${ }^{66}$ Muhammadi et al., ${ }^{67}$ Deloitte, ${ }^{68}$ and Palombo. ${ }^{69}$ As mentioned, the international trends in TP litigation are usually favourable to taxpayers, and the motives may not be very different from those believed to be at the origin of the Portuguese arbitration rulings. Results provide additional proof, from tax arbitration courts in this case, that TP is an area in which TAs do not have a successful litigation record. Litigated topics are quite similar in many jurisdictions with comparability issues at the forefront.

\section{Policy implications}

\section{I For Corporate Managers}

Multinational companies face increasing scrutiny by TAs. It is usual that $1 \%$ of companies (the ones that are internationalized, operate as groups, and have important tax planning teams) represent over $50 \%$ of corporate tax revenue. $^{70}$ TAs have created special departments (e.g. Big Taxpayers Special Unit) to audit these entities. Managers must be aware that TAs learn from an historical set of unsuccessful TP rulings. Consequently, the technical ability of tax auditors will increase, and the consistency of adjustments will improve.

The BEPS Report ${ }^{71,72}$ brought many tax avoidance strategies to the limelight that are linked to TP and tax codes being revised to make avoidance more difficult by exploiting TP as a minimization tool. The progressive implementation of the BEPS Action Plan, with a strong emphasis on TP and tax avoidance, is an additional factor that companies may consider in this area. This points to an increasingly adverse environment between managers and tax auditors. ${ }^{73}$

From a company's perspective, TP reports must be considered by tax auditors as carefully substantiated, comparability issues must be explained in detail, and methods that are chosen must be appropriately discussed. ${ }^{74}$ Moreover, documental proof of transactions and comparability issues (e.g. functions, financial conditions, market share) should be quantified and not briefly mentioned, as may happen in some cases.

Finally, when a firm outsources a TP report, it should cohesively cooperate with tax consultants. Sufficient information to sustain the usual core assertions in a TP - comparability, selected method, and sample selection - must be available. Other issues for which cooperation between managers and tax professionals may be increased are pricing strategies in intangibles transactions, accounting keys to cost allocation, intra group financial operations, and how interest rates are computed. ${ }^{75}$

\subsection{For TAs}

Three major issues should merit the critical attention of TAs in TP auditing. Firstly, tax auditors have less knowledge of businesses and, therefore, even if highly trained, may overlook some specific and unique issues that impact comparability. ${ }^{76}$ Secondly, companies are prone to litigate especially because TP adjustments involve international groups and are, on a monetary basis, quite significant. ${ }^{77}$ Finally, the worldwide trend in TP court rulings does not favour TAs.

Considering this background, on a policy level, the authors would argue for carefully substantiated audit reports. Senior audit team leaders with extensive practical experience are required, particularly if a major case is at stake. $^{78}$

Additionally, higher ranking officers should not fear a deep review of tax audits and should nudge junior auditors towards balanced conclusions. Junior auditors must be informed that professional chances of promotion do not depend on enormous adjustments emerging from superficially sustained reports but on the quality of the arguments and proof that underpin a TP review.

\section{Notes}

66 See Mudigonda, Kuo \& Thomas, supra n. 41.

67 See Muhammadi, Ahmed \& Habib, supra n. 2.

68 See Deloitte, supra n. 45.

69 See Palombo, supra n. 43.

70 See Government Accountability Office, Corporate Income Tax - Most Large Profitable US Corporations Paid Tax but Effective Tax Rates Differed Significantly from the Statutory Rate (2016).

71 See OECD, Addressing Base Erosion and Profit Shifting (OECD Publishing 2017), http://dx.doi.org/10.1787/9789264192744-en (accessed 16 Apr. 2020).

72 See OECD, Action Plan on Base Erosion and Profit Shifting (OECD Publishing 2017), http://dx.doi.org/10.1787/9789264202719-en (accessed 16 Apr. 2020).

See Bradley, supra n. 2.

74 See PT: Case 275/2014-T and PT: Case 423/2015-T.

75 See Chand, supra n. 7.

76 See e.g. PT: Case 844/2014-T and PT: Case 733/2015-T

See Padhi \& Bal, supra n. 23.

78 See PT: Case 101/2014-T, PT: Case 281/2015-T, and PT: Case 559/2015-T in which audit reports could, if scrutinized by a senior trained eye, have avoided legally unsustainable TP adjustments. 
Finally, TAs should not make appeal a default option. Appealing to higher ranking courts in cases when there is overwhelming evidence of incorrect use of comparables, of unstained method selection, or similar report deficiencies is a contribution to an increasing case load in courts and deteriorating what is already a contentious relationship with companies. ${ }^{79}$

\subsection{For Tax Legislators}

In such a complex and multidisciplinary area, it is not easy to produce concise, easy to interpret, and objective legislation.-

${ }^{80}$ However, legal clarity may be positively influenced if, in the legislative process, relevant stakeholders such as firms, tax auditors, tax consultants, and judges have the opportunity to comment on proposed legal texts. Additionally, TP rules should be richer in numerical examples and cases in order to illustrate intricate operations.

Tax legislators should also make advance price agreements a viable and frequently used alternative. ${ }^{81}$ That means establishing short time limits to produce them and decreasing their price.

The judicial system should also be aware that TP is a multidisciplinary area, constantly updating the financial, accounting, and other skills of judges who, while interpreting the law, must navigate these complex topics either in technical reports or when listening to expert witnesses.

\section{Conclusion}

Intra group transactions have increasingly come into the spotlight of worldwide TAs given the transactions' potential for profit shifting strategies related to transfer pricing. Following an increased scrutiny of such transactions, Portuguese TAs have been extending their transfer pricing audits and making frequent tax adjustments.
Topics such as the comparability principle, TP selected methods, the proper valuation of intangibles, or intra group finance are often the basis for court cases. The authors analysed all (thirty-two) TP cases decided by Portuguese tax arbitration courts and found that the general trend emerging from the literature illustrates a majority of rulings favouring taxpayers is also observable in Portugal in the context of an alternative resolution mechanism such as tax arbitration.

Tax audits presented ineffectiveness in comparability issues, in selecting TP methods, and by applying TP regulations when courts ascertained that no legal grounds existed for TP based adjustments.

On a policy level, TAs must put additional efforts toward producing substantiated adjustments by generating audit reports that are solidly grounded in corporate transactions paper trails and exhibiting proof of observation of TP regulations. Comparability issues and the selection of methods are at the forefront of improving TAs' court standing. On the side of firms, considering the increased scrutiny of TP reports, a careful analysis of transactions, the rigorous justification for the type of comparable used, selected methods, and the detailed explanation of economic conditions underpinning intra group transactions are essential to maintain a solid litigation standing.

Future research avenues that can be highlighted are surveying TAs regarding their perception of tax arbitration regarding to TP and also if they intend to change audit procedures to improve litigation outcomes. On the side of firms and consultants, it is relevant to know if TP reports have been changing in accordance with the authors' perception of better and a greater amount of solid evidence they must gather to successfully face increased scrutiny. Finally, the future study of how the BEPS Action Plan and subsequent legislation changed TP related profit shifting strategies is also a relevant research topic.

\section{Notes}

79 See Bradley, supra n. 2.

80 See OECD, supra n. 1

81 See P. Matos, F. Moura \& R. Rocha, Os acordos prévios de preço de transferência: uma ferramenta de modernização do enquadramento tributário $201-218$ (João T. Gama coord., Almedina 2013) 